\title{
Performance and electrochemical analysis of solid oxide fuel cells based on LSCF-YSZ nano-electrode
}

\author{
Jia, Chuan; Chen, Ming; Han, Minfang
}

Published in:

International Journal of Applied Ceramic Technology

Link to article, DOI:

10.1111/ijac.12748

Publication date:

2017

Document Version

Peer reviewed version

Link back to DTU Orbit

\section{Citation $(A P A)$ :}

Jia, C., Chen, M., \& Han, M. (2017). Performance and electrochemical analysis of solid oxide fuel cells based on LSCF-YSZ nano-electrode. International Journal of Applied Ceramic Technology, 14(5), 1006-1012.

https://doi.org/10.1111/ijac.12748

\section{General rights}

Copyright and moral rights for the publications made accessible in the public portal are retained by the authors and/or other copyright owners and it is a condition of accessing publications that users recognise and abide by the legal requirements associated with these rights.

- Users may download and print one copy of any publication from the public portal for the purpose of private study or research.

- You may not further distribute the material or use it for any profit-making activity or commercial gain

- You may freely distribute the URL identifying the publication in the public portal 


\title{
Performance and electrochemical analysis of solid oxide fuel cells based on LSCF-YSZ nano-electrode
}

\author{
Chuan Jia ${ }^{\mathrm{a}}$, Ming Chen ${ }^{*}$, Minfang $\operatorname{Han}^{* a, c}$
}

a. State Key Laboratory of Power Systems, Department of Thermal Engineering, Tsinghua University, Beijing, 100084, P.R. China

b. Department of Energy Conversion and Storage, Technical University of Denmark, Fredrikborgsvej 399, P.O. Box 49, DK-4000 Roskilde, Denmark

c. Tsinghua Innovation Center in Dongguan, Dongguan, 523808, P.R. China

Abstract: NiO-YSZ /YSZ/ LSCF-YSZ tri-layer structure SOFC has been fabricated by tape casting and infiltration methods. Subsequently, polarization curves and electrochemical impedance spectra measurement were carried out to evaluate cell performance at $850-700^{\circ} \mathrm{C}$ with varied steam content in hydrogen supplied to anode. At $800^{\circ} \mathrm{C}$, open circuit voltage for $4 \%$ steam humidified hydrogen has reached $1.069 \mathrm{~V}$, along with power density of $831 \mathrm{~mW} \mathrm{~cm}^{-2}$ at $0.7 \mathrm{~V}$. Furthermore, $500 \mathrm{~h}$ of long-term durability test has been performed at $750^{\circ} \mathrm{C}$ in hydrogen atmosphere, as a consequence that a voltage degradation rate of $1.7 \% / \mathrm{kh}$ has been measured.

Keywords: LSCF-YSZ, SOFC, electrochemical analysis, DRT

I Introduction

Solid oxide fuel cell (SOFC) has attracted increased attention as energy-converting 
device, which can directly convert chemical energy to electricity. [1] Because of its high electronic and oxygen ion conductivities at low temperatures, the strontium- and cobalt-doped lanthanum ferrites, $\mathrm{Lax}_{x} \mathrm{Sr}_{1-\mathrm{x}} \mathrm{Co}_{y} \mathrm{Fe}_{1-\mathrm{y}} \mathrm{O}_{3-\delta}(\mathrm{LSCF})$, have been widely used as cathode materials for intermediate and low temperature SOFCs. Yttria-stabilized zirconia (YSZ) is the state-of-the-art electrolyte material for SOFC. Nickel oxide (NiO)-YSZ as anode material in combination with YSZ electrolyte and LSCF cathode has been investigated by many researchers [2-6].

To decrease the sintering temperature of the cell, lots of works have been focused on infiltration method, which is used to fabricate the cathode of SOFC. Liu et al. prepared a tri-layer YSZ structured SOFC infiltrated with LSCF and Pd-SDC respectively acting as cathode and anode, which shows good power density of $935 \mathrm{~mW}$ $\mathrm{cm}^{-2}$ at $800^{\circ} \mathrm{C}$ [3]. Fan et al. also prepared LSCF-YSZ nano-electrode with infiltration for reversible SOFCs [7], showing high catalytic activity towards oxygen reduction/oxidation reaction. However, analysis of electrochemical impedance spectra of infiltrated cells is rarely reported [8]. What's more, long-term stability of the electrode fabricated by infiltration method is a critical issue. It has been reported that coarsening of infiltrated nano-particles and solid reactions between the infiltrated and scaffold material are the potential causes for the degradation $[9,10]$. Meanwhile, longterm stability results of infiltration electrodes are rarely published.

Distributions of relaxation times (DRT) is a technique for deconvolution of a single impedance spectrum into a distribution of relaxation times, invented by Ivers-Tiffée and coworkers [11]. According to DRT method, different electrode processes in SOFC 
can be identified. The impedance $Z$ for angular velocity $\omega$ can be decomposed as

$$
\begin{aligned}
Z(\omega) & =R_{0}+Z_{p o l}(\omega) \\
& =R_{0}+R_{p o l} \int_{0}^{\infty} \frac{\gamma(\tau)}{1+j \omega \tau} \mathrm{d} \tau=R_{0}+R_{p o l} \int_{0}^{\infty} \frac{G(\tau)}{1+j \omega \tau} \mathrm{d} \ln \tau
\end{aligned}
$$

in which $R_{0}$ is ohmic resistance irrelevant to frequency, $Z_{p o l}(\omega)$ is the polarization part of total impedance. By using DRT technique, different physical and chemical procedures are shown as different peaks with characteristic frequencies, which can be distinguished with the change of test conditions.

In this study, nano-structural LSCF-YSZ electrode for planar SOFC was fabricated with infiltration method. After that, analysis of electrochemical impedance spectra was carried out using DRT method to evaluate the performance of infiltrated cells. Longterm stability test was also implemented with humidified hydrogen at $750^{\circ} \mathrm{C}$ for $500 \mathrm{~h}$. EIS data was fitted to an equivalent circuit model by the Complex Nonlinear Least Square (CNLS) method. Finally, scanning electron microscope (SEM) photos of test cells before and after long-term stability test were given.

\section{Experimental}

\subsection{Preparation of nano-structured NiO-YSZ/YSZ/LSCF-YSZ cells}

The procedure for preparation of tested SOFC is mentioned in ref. [12]. The cell was fabricated by tape casting and infiltration methods. The NiO-YSZ/YSZ/porous YSZ substrate was firstly made by tape casting and hot isostatic pressing technology. YSZ (8 mol\% yttria stabilized zirconia, Tosoh Company, Japan), NiO powder and graphite (Furunda Zirconium Material Co. Ltd., China) as pore former were mixed in a 
weight ratio of 50:50:10 and ball milled with ethanol-butanone solvent, castor oil dispersant, dibutyl phthalate (DBP) plasticizer, and polyvinyl butyral (PVB) binder in a two-stage milling process mentioned in [7]. For preparation of the YSZ electrolyte slurry, almost the same method was used, except for no $\mathrm{NiO}$ and graphite pore former. And the porous YSZ layer as cathode was also similar with $50 \mathrm{wt} \%$ graphite to form backbones. After tape casting and hot isostatic pressing mentioned in [3], the tri-layer structure cell substrate was co-sintered in air at $1300^{\circ} \mathrm{C}$ for $10 \mathrm{~h}$ to get the YSZ electrolyte layer densified. After that, LSCF ( $\left.\mathrm{La}_{0.6} \mathrm{Sr}_{0.4} \mathrm{Co}_{0.2} \mathrm{Fe}_{0.8} \mathrm{O}_{3-\delta}\right)$ precursor as the solution of infiltration was prepared by dissolving stoichiometric amounts of $\mathrm{La}\left(\mathrm{NO}_{3}\right)_{3} \cdot 6 \mathrm{H}_{2} \mathrm{O}, \mathrm{Sr}\left(\mathrm{NO}_{3}\right)_{2}, \mathrm{Co}\left(\mathrm{NO}_{3}\right)_{2} \cdot 6 \mathrm{H}_{2} \mathrm{O}$ and $\mathrm{Fe}\left(\mathrm{NO}_{3}\right)_{3} \cdot 9 \mathrm{H}_{2} \mathrm{O}$ in deionized water and ethanol. [13] The infiltration process was executed by infiltrating solution into presintered YSZ backbone. After infiltration and dried in air at room temperature, the substrate was sintered at $450^{\circ} \mathrm{C}$ for $2 \mathrm{~h}$ to let nitrate decompose to oxide. This procedure was repeated for multiple times until the loading amount of LSCF reaching 30 50 wt $\%$ and finally the cells were sintered at $900^{\circ} \mathrm{C}$ for $2 \mathrm{~h}$ to obtain nano-structured cathode.

2.2 Procedures of cell characterization, electrochemical measurement and long-term test in hydrogen atmosphere

The prepared NiO-YSZ/YSZ/LSCF-YSZ cells were cut with an effective working area of $4 \times 4 \mathrm{~cm}^{2}$. The cells were tested in a SOFC test setup mentioned in [14]. Gold and double-layer nickel meshes were used as current collectors on the oxygen and fuel side, respectively. 


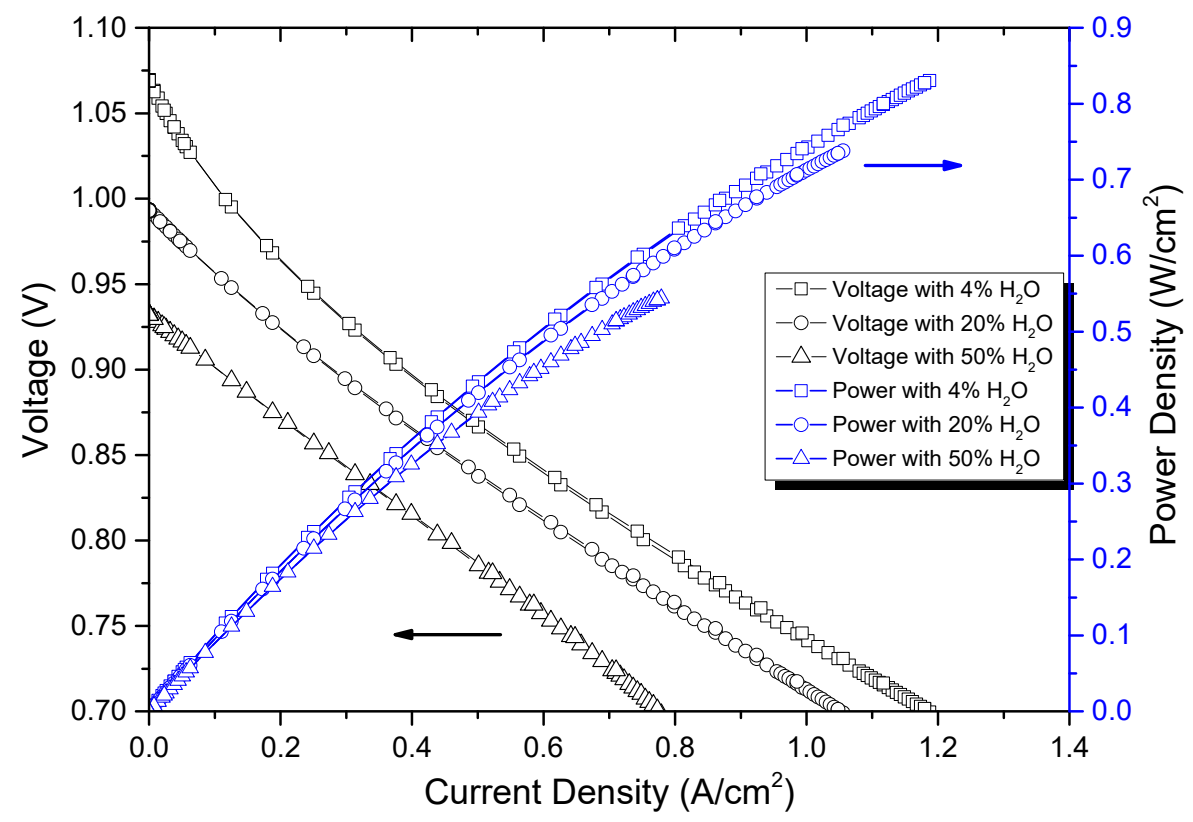

Fig. 1 Performance of test cell at $800^{\circ} \mathrm{C}$ with different fuel components supplied to anode side

Before testing, NiO-YSZ anode was reduced at $850^{\circ} \mathrm{C}$ in safety hydrogen $(9 \%$ hydrogen, $91 \%$ nitrogen) for $2 \mathrm{~h}$. The electrochemical measurement procedures of the cell were executed at temperatures from $850^{\circ} \mathrm{C}$ to $700^{\circ} \mathrm{C}$ with a decrement of $50^{\circ} \mathrm{C}$, during which $24 \mathrm{~L} / \mathrm{h}$ hydrogen with $4 \%, 20 \%$ and $50 \%$ steam content supplied to NiOYSZ anode, and $140 \mathrm{~L} / \mathrm{h}$ air supplied to LSCF-YSZ cathode for each temperature. To protect test cells, the lowest voltage applied in $\mathrm{i}-\mathrm{V}$ test was limited to $700 \mathrm{mV}$. Electrochemical impedance spectroscopy (EIS) of test cells was measured at OCV by using Solatron 1260 frequency analyzer and external shunt in series with the cell. 12 points per decade was recorded from $96,850 \mathrm{~Hz}$ to $0.08 \mathrm{~Hz}$. Analysis of impedance data via DRT method was carried out using Ravdav [15]. 500h long-term stability test was examined at $750^{\circ} \mathrm{C}$ by introducing $24 \mathrm{~L} / \mathrm{h}$ hydrogen with $4 \%$ steam content to anode and $140 \mathrm{~L} / \mathrm{h}$ air to cathode, at the current density of $0.25 \mathrm{~A} \mathrm{~cm}^{-2}$. EIS data was collected 
during test at $\mathrm{OCV}$ with an $\mathrm{AC}$ amplitude of $20 \mathrm{mV}$.

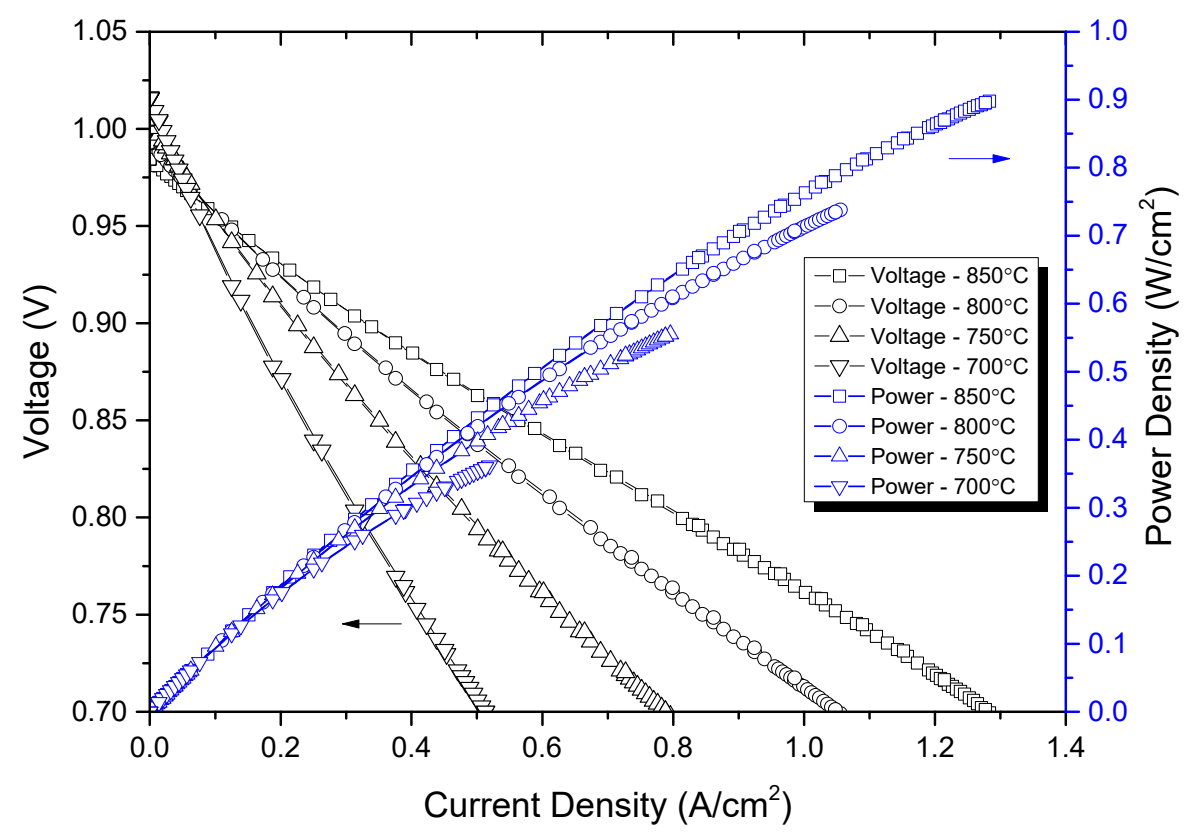

Fig. 2 Performance of test cell at different temperatures with $20 \%$ steam hydrogen supplied to anode side

III Results and discussion

\subsection{Cell characterization of polarization curves}

Fig. 1 shows the cell voltage and power density change as function of current density at $800^{\circ} \mathrm{C}$ with different steam contents of hydrogen to anode side. From Fig. 1, it can be seen that peak power densities of the cell were about $831 \mathrm{~mW} \mathrm{~cm}^{-2}, 738 \mathrm{~mW}$ $\mathrm{cm}^{-2}$ and $544 \mathrm{~mW} \mathrm{~cm} \mathrm{~cm}^{-2}$ at $0.7 \mathrm{~V}$ for hydrogen with $4 \%, 20 \%$ and $50 \%$ steam supplied to anode, respectively. Open circuit voltage for 4\% steam humidified hydrogen reached $1.069 \mathrm{~V}$ and maximum current density reached $1.2 \mathrm{~A} \mathrm{~cm}^{-2}$, indicating densified electrolyte and relatively low resistance. Moreover, the activation loss for $4 \%$ steam humidified hydrogen is apparently higher. 
Fig. 2 shows i-V curves at different temperatures from $850^{\circ} \mathrm{C}$ to $700^{\circ} \mathrm{C}$ with $20 \%$ steam humidified hydrogen. The open circuit voltages reached $0.985 \mathrm{~V}, 0.994 \mathrm{~V}, 1.004 \mathrm{~V}$ and $1.016 \mathrm{~V}$ at $850^{\circ} \mathrm{C}, 800^{\circ} \mathrm{C}, 750^{\circ} \mathrm{C}$ and $700^{\circ} \mathrm{C}$, respectively. Maximum power density of $898 \mathrm{~mW} \mathrm{~cm}^{2}$ was measured at $850^{\circ} \mathrm{C}$ Resistance of test cell increased as expected with the decrease of temperature with ohmic resistance $\left(R_{s}\right)$ of $0.08,0.11,0.15,0.22 \Omega$ $\mathrm{cm}^{2}$ and polarization resistance $\left(\mathrm{R}_{\mathrm{p}}\right)$ of $0.22,0.28,0.39,0.64 \Omega \mathrm{cm}^{2}$ at $850^{\circ} \mathrm{C}, 800^{\circ} \mathrm{C}$, $750^{\circ} \mathrm{C}$ and $700^{\circ} \mathrm{C}$, respectively, which can be deduced from Fig. 4.

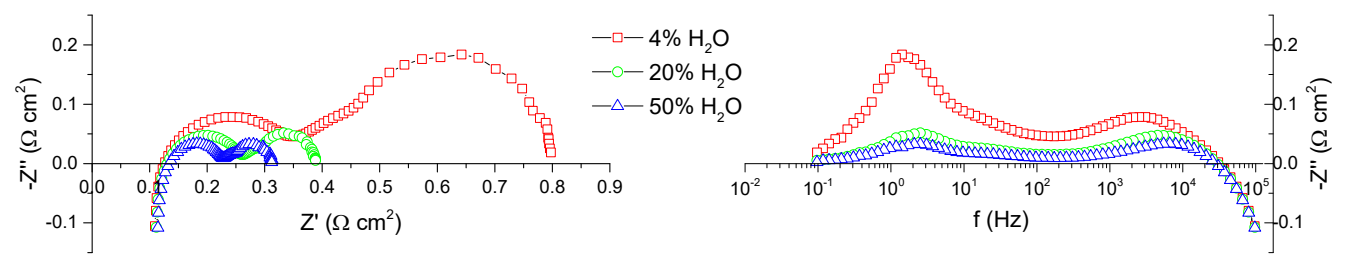

Fig. 3 EIS results of test cell at $800^{\circ} \mathrm{C}$ with different fuel components supplied to anode side

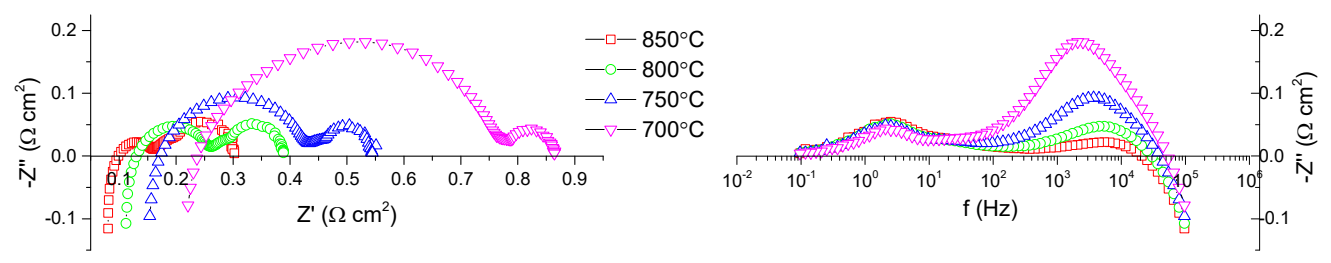

Fig. 4 EIS results of test cell at different temperatures with $20 \%$ steam hydrogen supplied to anode side

\subsection{Electrochemical impedance spectra measurement}

Fig. 3 and Fig. 4 show the EIS results related to Fig. 1 and Fig. 2, respectively. From Fig. 3, it is clear that steam content influenced polarization resistance significantly, whereas ohmic resistance remained constant. Both high frequency and low frequency arcs in spectra were varied with the change of steam content, indicating that the fuel composition has an effect on almost all physical and chemical procedures in tri-layer structure fuel cells tested, especially for low frequency arc. On the other 
hand, temperature exerted an influence on both ohmic and polarization resistance as expected. Almost no influence of temperature can be seen from low frequency arc in spectra, with significantly rise of high frequency arc as the temperature decreased. This illustrated different temperature reaction of physical and chemical processes.

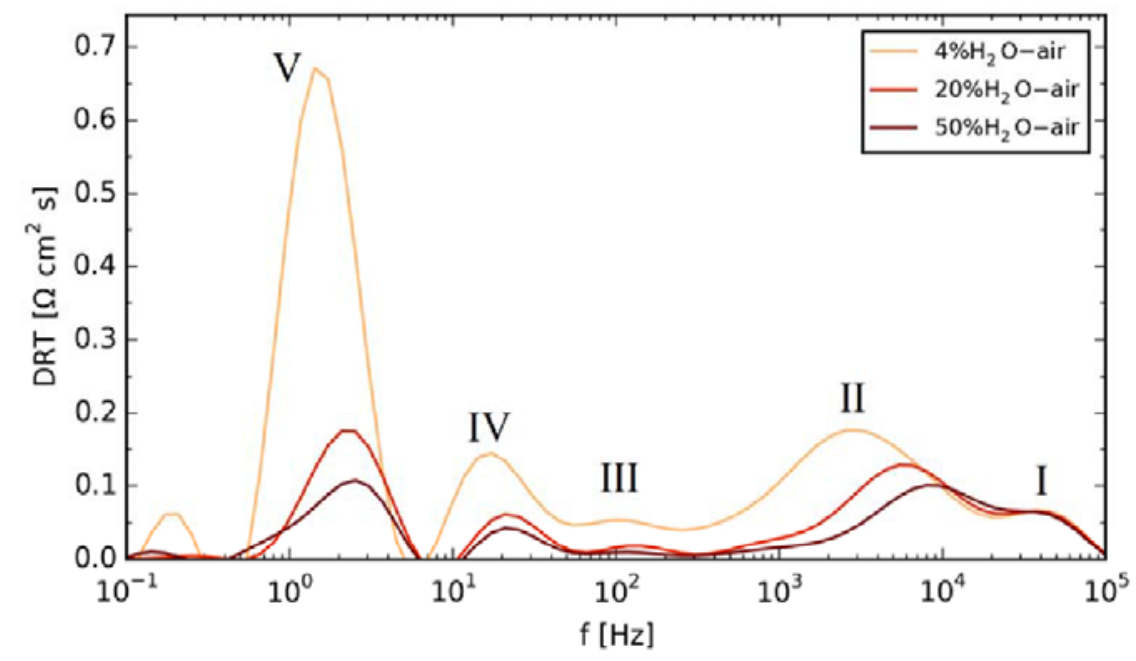

Fig. 5 DRT analysis of EIS data of test cell at $800{ }^{\circ} \mathrm{C}$ with different fuel components supplied to anode side

DRT analysis of EIS data in Fig. 3 and Fig. 4 are shown in Fig. 5 and Fig. 6. Five peaks can be observed in DRT curves, namely Peak I to Peak V starting from high frequency. According to results by other researchers, Peak I to V corresponded to ionic transport [16], Triple Phase Boundary (TPB) reaction [17], resistance of $\mathrm{O}^{2-}$ diffusivity [17] in cathode, diffusion [18] and conversion [19] in anode, respectively. According to Fig. 5, Peak I remained constant when steam content changed in anode side, indicating ionic transport on cathode side, which is different from the results in [18]. All the other 4 peaks are related to the change of fuel compositions in anode side. And their characteristic frequencies all increased with the increase of steam content in hydrogen. For Fig. 6, two groups can be distinguished clearly. Peak I and II are 
temperature-dependent peaks, and the heights of peaks increased with the decrease of temperature. The characteristic frequency of Peak II decreased at the same time, while that of Peak I remained unchanged. Peak III, IV and V are temperature-independent peaks, which means their peak heights and characteristic frequencies remained unchanged with temperature decrease, indicating that the related processes in test cells are temperature-independent. The peaks and their characteristic frequency ranges are listed in Table 1.

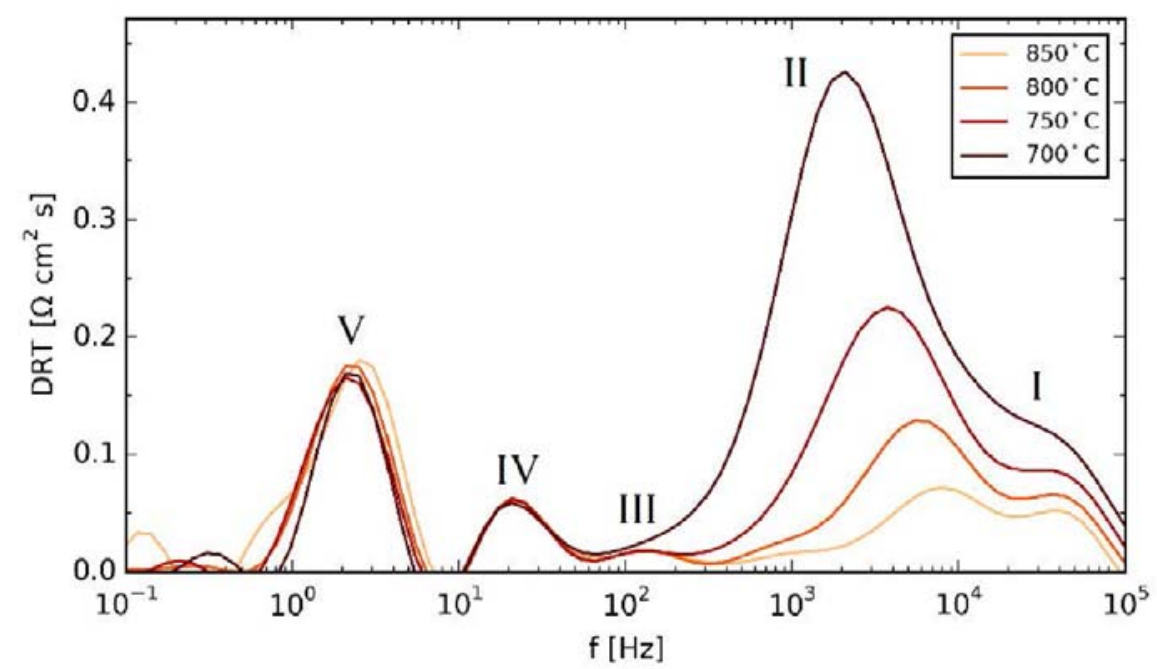

Fig. 6 DRT analysis of EIS data of test cell at different temperatures with $20 \%$ steam hydrogen supplied to anode side

Table 1 characteristic frequency range of peaks in DRT analysis of test cells

\begin{tabular}{cccccc}
\hline Peak No. & I & II & III & IV & V \\
\hline characteristic & & & & & \\
frequency & $10 \mathrm{k} \sim 50 \mathrm{k}$ & $1 \mathrm{k} \sim 10 \mathrm{k}$ & $100 \sim 200$ & $10 \sim 40$ & $1 \sim 4$ \\
range $(\mathrm{Hz})$ & & & & & \\
\hline
\end{tabular}


3.3 Long-term test in hydrogen atmosphere

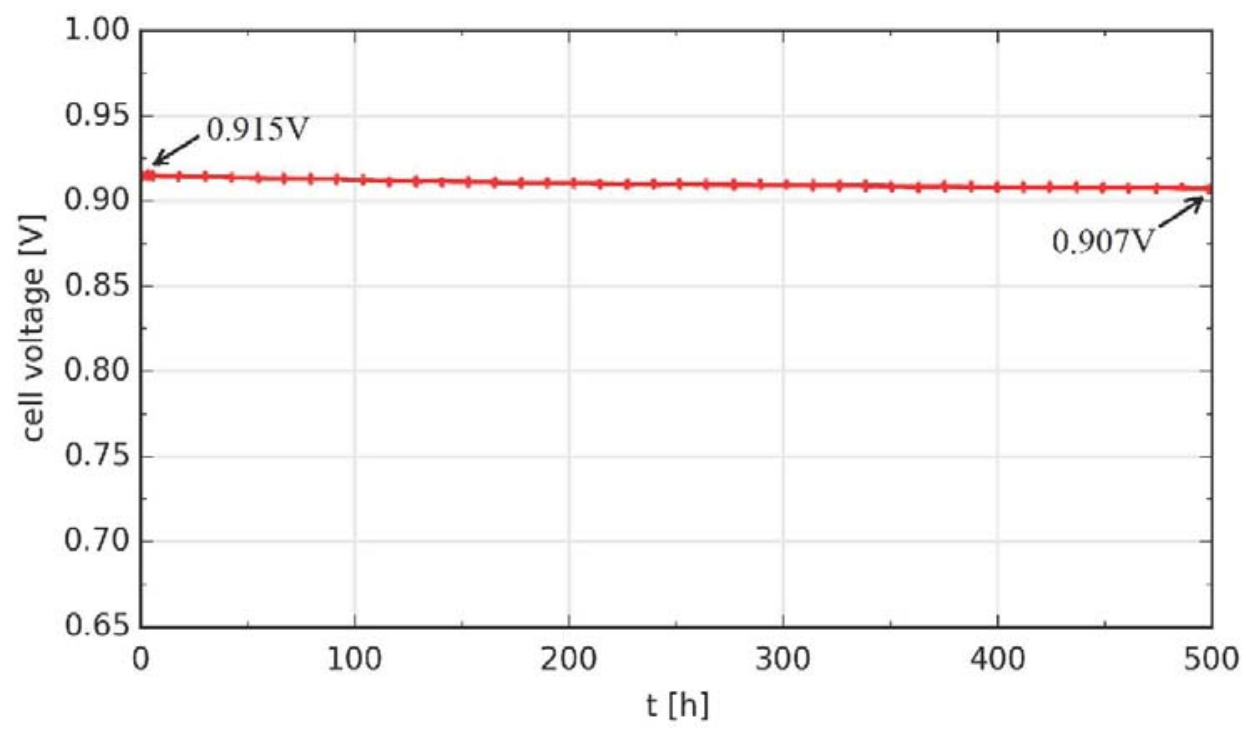

Fig. 7 i-V result of long-term test of test cell

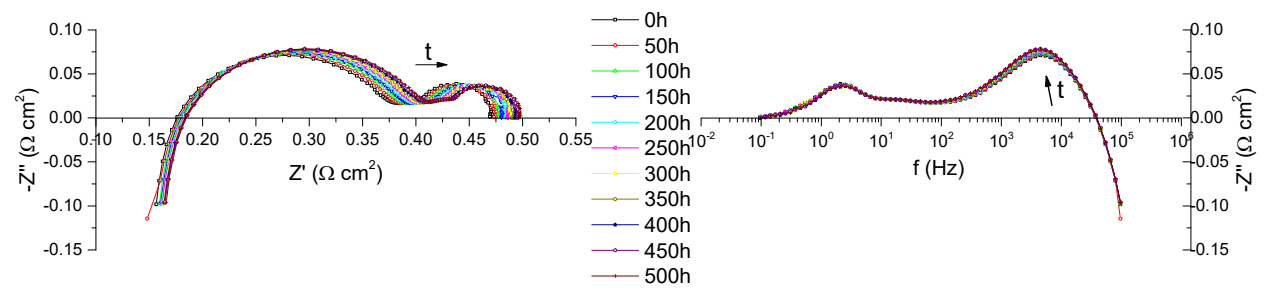

Fig. 8 EIS result of long-term test of test cell

$500 \mathrm{~h}$ test with $4 \%$ steam humidified hydrogen as fuel at $750^{\circ} \mathrm{C}$ was performed after cell electrochemical characterization. The current density was set to be $0.25 \mathrm{~A} \mathrm{~cm}^{-2}$. I$\mathrm{V}$ result is shown in Fig. 7. Cell voltage dropped from $0.915 \mathrm{~V}$ at the beginning to $0.907 \mathrm{~V}$ at the end of the test, indicating a voltage degradation rate of $1.7 \% / \mathrm{kh}$, close to similar tests [20]. EIS results during long-term test are presented in Fig. 8. As it can be seen, ohmic resistance increased slightly from $0.17 \Omega \mathrm{cm}^{2}$ to $0.18 \Omega \mathrm{cm}^{2}$, while polarization resistance increased from $0.31 \Omega \mathrm{cm}^{2}$ to $0.33 \Omega \mathrm{cm}^{2}$, mainly in high frequency arc. 


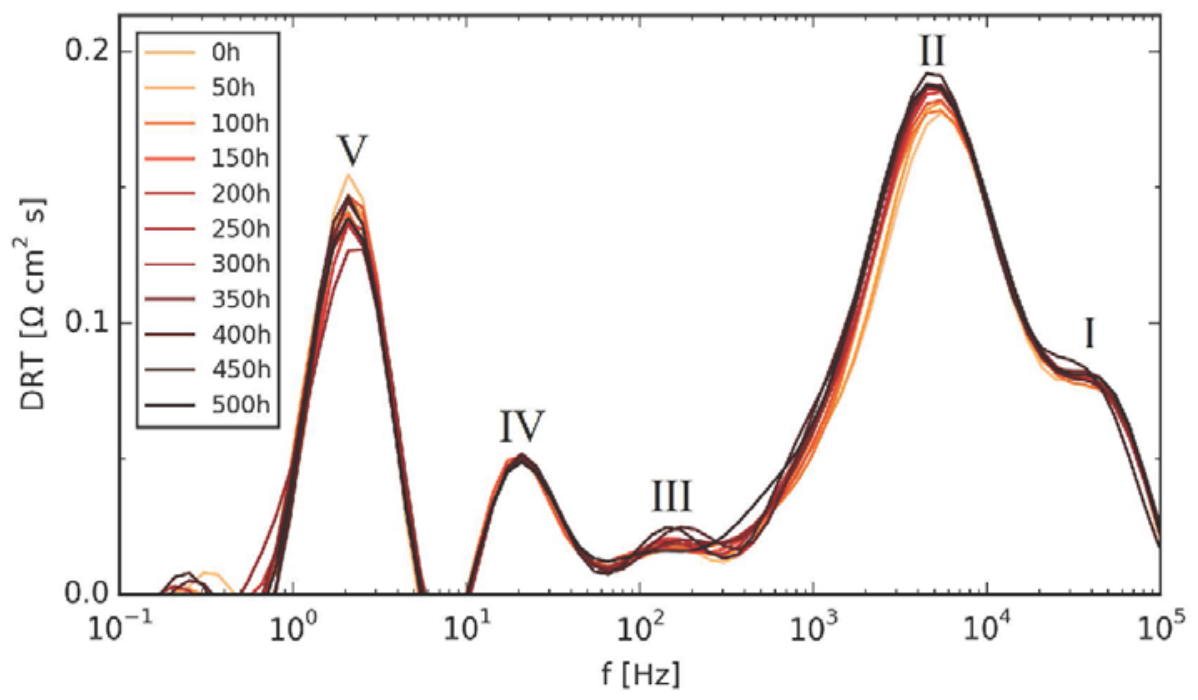

Fig. 9 DRT analysis of EIS data of long-term test of test cell

DRT analysis of EIS data is presented in Fig. 9. As shown in the graph, increase of impedance is mainly due to the increase of Peak II, while Peak V showed a slightly tendency of decrease during test. The characteristic frequency of Peak II also decreased slightly with time, which by far has not been noticed before. Previous research has mentioned relation between the long-term performance degradation and the coarsening of microstructure of test cell, which leads to reduction of TPB [7, 21-23]. These corresponded to the phenomenon of Peak II, which was possibly the potential cause of degradation of cell performance.

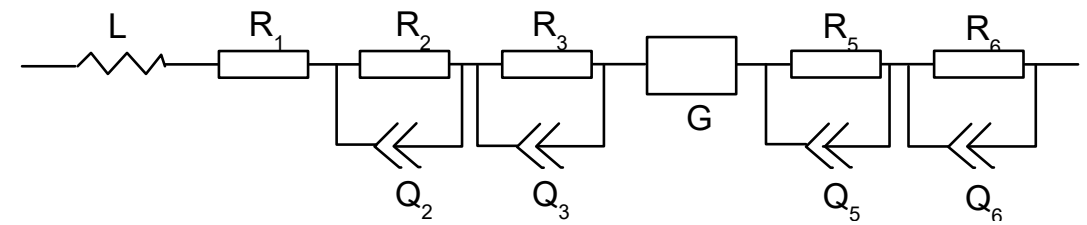

Fig. 10 Equivalent circuit for test cell

Each resistance was fitted by the CNLS method using an equivalent circuit of Fig.

10. Resistances and constant phase elements were combined to simulate electric behavior of Peak I, II, IV and V, while a Gerischer element was used to simulate behavior of $\mathrm{O}^{2-}$ diffusion in cathode, which was represented by Peak III. 


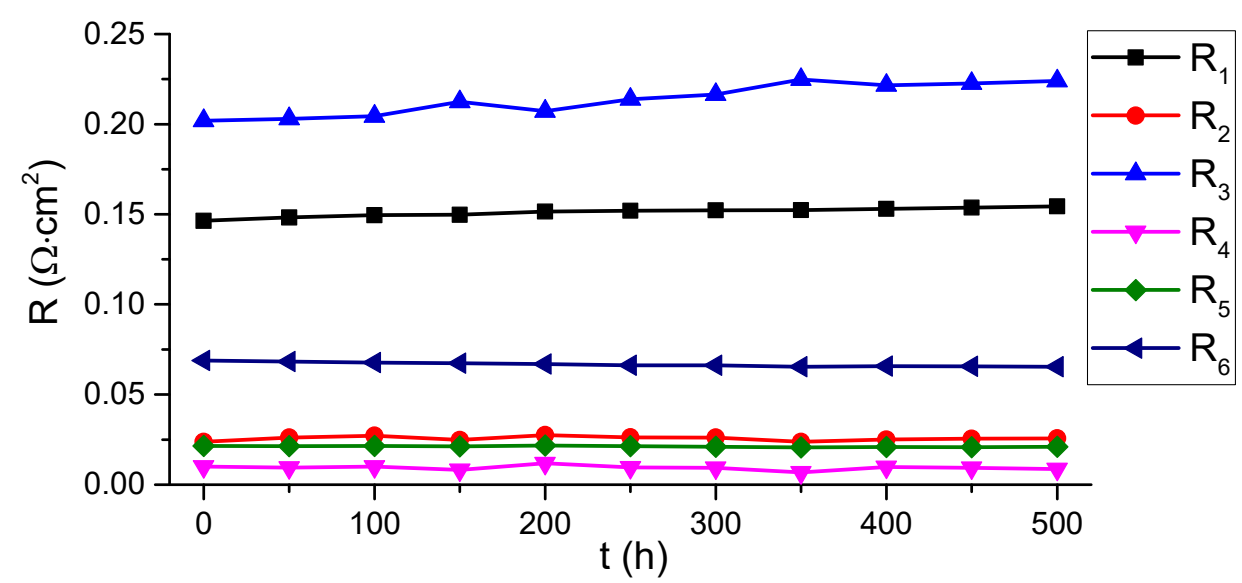

Fig. 11 Fitting results of impedance data of long-term stability test

Fitting results are shown in Fig. 11. We can see that the resistance of Peak II $\left(\mathrm{R}_{3}\right)$ contributed most to the imcrease of impedance of test cell. It increased from $0.202 \Omega$ $\mathrm{cm}^{2}$ at $0 \mathrm{~h}$ to $0.224 \Omega \mathrm{cm}^{2}$.at $500 \mathrm{~h}$. Ohmic resistance $\left(\mathrm{R}_{1}\right)$ also increased with time from $0.146 \Omega \mathrm{cm}^{2}$ to $0.154 \Omega \mathrm{cm}^{2}$. The resistances of other peaks were all below $0.1 \Omega \mathrm{cm}^{2}$ and their contribution to the change of total impedance can be ignored. Changing rates of every resistance are listed in Table 2 . It has to be mentioned that the changing rate for $\mathrm{R}_{2}, \mathrm{R}_{4}, \mathrm{R}_{5}, \mathrm{R}_{6}$ are more likely to be affected by random data error because of relatively smaller resistance value.

Table 2 changing rates of resistance in the equivalent circuit in long-term test

\begin{tabular}{ccccccc}
\hline resistance & $\mathrm{R}_{1}$ & $\mathrm{R}_{2}$ & $\mathrm{R}_{3}$ & $\mathrm{R}_{4}$ & $\mathrm{R}_{5}$ & $\mathrm{R}_{6}$ \\
\hline changing & & & & & & \\
rate $(\% / \mathrm{kh})$ & 9.6 & -2.4 & 24.8 & -25.7 & -6.76 & -10.2 \\
\hline
\end{tabular}

SEM photos of testing cell before and after long-term stability test are shown in Fig.12. In the middle is the dense YSZ electrolyte layer, which is about $10 \mathrm{~mm}$ in thickness. Above that is the LSCF/YSZ cathode layer and below is the YSZ/NiO anode 
layer. The vertical cracks in the electrolyte layer in Fig. 12b) was caused by cell dismounting. By comparison, no obvious change in cell structure can be observed, while the change of micro-structure needs to be investigated further due to lack of high resolution equipment.

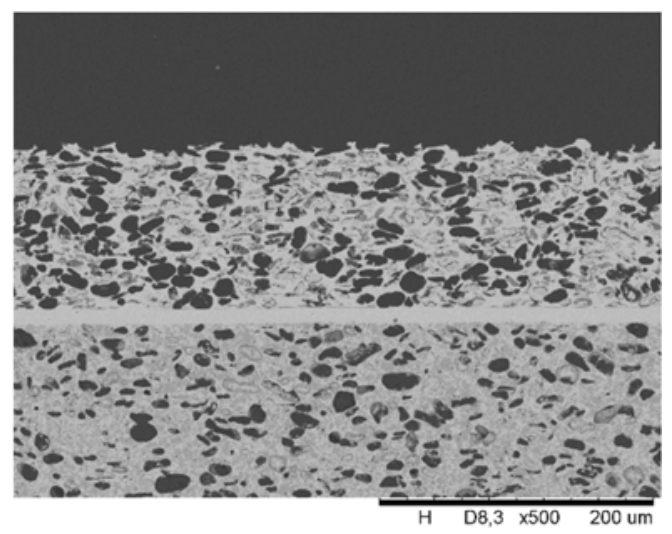

a)

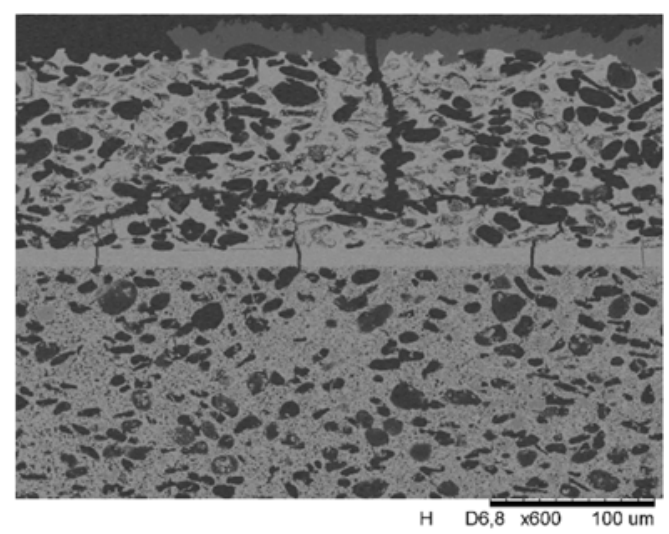

b)

Fig. 12 SEM photos of testing cell for long-term test

a) before test $b$ ) after test

IV Conclusion

Cell characterization, electrochemical measurement and 500h durability test were executed for NiO-YSZ/YSZ/LSCF-YSZ tri-layer structure SOFC. Power density of $831 \mathrm{~mW} \mathrm{~cm}{ }^{2}$ at $0.7 \mathrm{~V}$ at $800^{\circ} \mathrm{C}$ was reached. Five different reaction processes have been distinguished by DRT analysis. 1.7\%/kh degradation rate was measured for 500 durability test, and coarsening of microstructure was suspected to be the potential cause for degradation.

\section{Acknowledgement}

This work is supported by One-Hundred Leading Talents Development Project for Progress on Science and Technology of Beijing (No. Z151100000315031), Coal-based 
Key Scientific and Technological Project from The Shanxi Science and Technology Department (No. MD2014-08), State Key Laboratory of Power Systems at Tsinghua University (No. SKLD15Z02, No. SKLD16Z11), Tsinghua- RWTH Aachen Collaborative Innovation Project (No. IDM-201603), and Guangdong Project (201460720100025).

Reference:

[1] Zhao Y, Xia C, Jia L, et al. Recent progress on solid oxide fuel cell: lowering temperature and utilizing non-hydrogen fuels. International Journal of Hydrogen Energy. 2013;38:16498-16517.

[2] Steele BC. Survey of materials selection for ceramic fuel cells II. Cathodes and anodes. Solid State Ionics. 1996;86:1223-1234.

[3] Liu Z, Zheng ZW, Han MF, et al. High performance solid oxide fuel cells based on tri-layer yttria-stabilized zirconia by low temperature sintering process. Journal of Power Sources. 2010;195:7230-7233.

[4] Liu Y, Chen J, Wang F, et al. Performance stability of impregnated $\mathrm{La} 0.6 \mathrm{Sr}_{0.4} \mathrm{Co} 0.2 \mathrm{Fe}_{0.8} \mathrm{O}_{3-\delta}-\mathrm{Y}_{2} \mathrm{O}_{3}$ stabilized $\mathrm{ZrO}_{2}$ cathodes of intermediate temperature solid oxide fuel cells. International Journal of Hydrogen Energy. 2014;39:3404-3411.

[5] Zhao E, Jia Z, Liu X, et al. Stability of nanorod-structured $\mathrm{La}_{0.8} \mathrm{Sr}_{0.2} \mathrm{Co}_{0.2} \mathrm{Fe}_{0.8} \mathrm{O}_{3-\delta^{-}}$ $\mathrm{Gd}_{0.2} \mathrm{Ce}_{0.8} \mathrm{O}_{1.9}$ composite cathodes for intermediate temperature solid oxide fuel cells. Ceramics International. 2014;40:14891-14898. 
[6] Liu Y, Wang F, Chi B, et al. A stability study of impregnated LSCF-GDC composite cathodes of solid oxide fuel cells. Journal of Alloys and Compounds. $2013 ; 578: 37-43$

[7] Fan H, Keane M, Li N, et al. Electrochemical stability of $\mathrm{La} 0.6 \mathrm{Sr} 0.4 \mathrm{Co}_{.2} \mathrm{Fe}_{0.8} \mathrm{O}_{3-\delta}-$ infiltrated YSZ oxygen electrode for reversible solid oxide fuel cells. International Journal of Hydrogen Energy. 2014;39:14071-14078.

[8] Li M, Zheng M, Hu B, et al. Improving electrochemical performance of lanthanum strontium ferrite by decorating instead of doping cobaltite. Electrochimica Acta. 2017;230:196-203.

[9] Tucker MC, Lau GY, Jacobson CP, et al. Stability and robustness of metalsupported SOFCs. Journal of Power Sources. 2008;175:447-451.

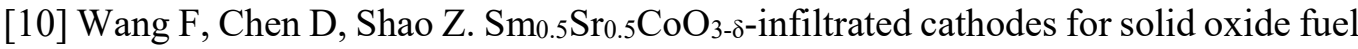
cells with improved oxygen reduction activity and stability. Journal of Power Sources. 2012;216:208-15.

[11] Müller A, Schichlein H, Feuerstein M, et al. Identification of Polarisation Processes in SOFC Electrodes. In: Singhal SC and Dokiya M, eds. Proceedings of the 6th International Symposium on Solid Oxide Fuel Cells (SOFC VI), The Electrochemical Society. Honolulu, 1999;99:925-931.

[12] Fan H, Han MF. Improved performance and stability of Ag-infiltrated nanocomposite $\mathrm{La} 0.6 \mathrm{Sr}_{0.4} \mathrm{Co}_{0.2} \mathrm{Fe}_{0.8} \mathrm{O}_{3-\delta}-\left(\mathrm{Y}_{2} \mathrm{O}_{3}\right)_{0.08}\left(\mathrm{ZrO}_{2}\right)_{0.92}$ oxygen electrode for $\mathrm{H}_{2} \mathrm{O} / \mathrm{CO}_{2}$ co-electrolysis. Journal of Power Sources. 2016;336:179-185.

[13] Chen KF, Ai N, Jiang SP. Reasons for the high stability of nano-structured (La, 
$\mathrm{Sr}) \mathrm{MnO}_{3}$ infiltrated $\mathrm{Y}_{2} \mathrm{O}_{3}-\mathrm{ZrO}_{2}$ composite oxygen electrodes of solid oxide electrolysis cells. Electrochem Commun. 2012;19:119-22.

[14] Mogensen M, Larsen PH, Hendriksen PV, et al. Solid oxide fuel cell testing: Results and interpretation. In: Singhal SC and Dokiya M, eds. Proceedings of the 6th International Symposium on Solid Oxide Fuel Cells (SOFC VI), The Electrochemical Society. Honolulu, 1999;99:904-915.

[15] Graves C. RAVDAV Data Analysis Software, Version 0.9.7, 2012.

[16] Jensen SH, Hauch A, Hendriksen PV, et al. A Method to Separate Process Contributions in Impedance Spectra by Variation of Test Conditions. Journal of The Electrochemical Society. 2007;154:B1325-B1330.

[17] Sumi H, Yamaguchi T, Hamanoto K, et al. AC impedance characteristics for anode-supported microtubular solid oxide fuel cells. Electrochimica Acta. 2012;67:159-165.

[18] Leonide A, Rüger B, Weber A, et al. Impedance Study of Alternative (La,Sr)FeO ${ }_{3-\delta}$ and (La,Sr)(Co,Fe)O $3-\delta$ MIEC Cathode Compositions. Journal of The Electrochemical Society. 2010;157:B234-B239.

[19] Primdahl S, Mogensen M. Gas Conversion Impedance: A Test Geometry Effect in Characterization of Solid Oxide Fuel Cell Anodes. Journal of The Electrochemical Society. 1998;145:2431-2438.

[20] Mai A, Becker M, Assenmacher W, et al. Time-dependent performance of mixedconducting SOFC cathodes. Solid State Ionics. 2006;177:1965-1968.

[21] Wang WS, Gross MD, Vohs JM, et al. The stability of LSF-YSZ electrodes 
prepared by infiltration. Journal of The Electrochemical Society. 2007;154:B439B445.

[22] Shah M, Voorhees PW, Barnett SA. Time-dependent performance changes in LSCF-infiltrated SOFC cathodes: The role of nano-particle coarsening. Solid State Ionics. 2011;187:64-67.

[23] Liu Y, Wang F, Chi B, et al. A stability study of impregnated LSCF-GDC composite cathodes of solid oxide fuel cells. Journal of Alloys and Compounds. 2013;578:37-43. 